\title{
Colwellia polaris sp. nov., a psychrotolerant bacterium isolated from Arctic sea ice
}

\author{
De-Chao Zhang, ${ }^{1}$ Yong Yu, ${ }^{2}$ Yu-Hua Xin, ${ }^{1}$ Hong-Can Liu, ${ }^{1}$ Pei-Jin Zhou ${ }^{1}$ \\ and Yu-Guang Zhou ${ }^{1}$
}

Correspondence

Yu-Guang Zhou

zhouyg@sun.im.ac.cn

\author{
${ }^{1}$ China General Microbiological Culture Collection Center and State Key Laboratory of Microbial \\ Resources, Institute of Microbiology, Chinese Academy of Sciences, Beijing 100101, PR China \\ ${ }^{2}$ SOA Key Laboratory for Polar Science, Polar Research Institute of China, Shanghai 200136, \\ PR China
}

A novel psychrotolerant, Gram-negative, aerobic bacterium, designated strain $537^{\top}$, was isolated from sea-ice samples from the Arctic. Strain $537^{\top}$ was able to grow at $4-26{ }^{\circ} \mathrm{C}$, with optimum growth occurring at $20-21^{\circ} \mathrm{C}$. Strain $537^{\top}$ had Q-8 as the major respiratory quinone and contained iso- $\mathrm{C}_{15: 0} 2-\mathrm{OH}$ and/or $\mathrm{C}_{16: 1} \omega 7 \mathrm{c}(22.95 \%), \mathrm{C}_{15: 1}(17.64 \%)$ and $\mathrm{C}_{17: 1} \omega 8 \mathrm{c}$ $(13.74 \%)$ as the predominant cellular fatty acids. The genomic DNA G $+\mathrm{C}$ content was $38.9 \mathrm{~mol} \%$. A phylogenetic analysis based on 16S rRNA gene sequences indicated that strain $537^{\top}$ formed a coherent cluster within the genus Colwellia. The highest level of 16S rRNA gene sequence similarity $(97.5 \%)$ exhibited by strain $537^{\top}$ was obtained with respect to the type strain of Colwellia aestuarii. On the basis of phenotypic, chemotaxonomic and phylogenetic properties and DNA-DNA relatedness data, strain $537^{\top}$ represents a novel species of the genus Colwellia, for which the name Colwellia polaris sp. nov. is proposed. The type strain is $537^{\top}$ $\left(=\right.$ CGMCC $1.6132^{\top}=$ JCM $\left.13952^{\top}\right)$.
The family Colwelliaceae, which includes the genera Colwellia and Thalassomonas, accommodates bacteria that are Gram-negative, seawater-requiring, chemo-organotrophic, curved or straight rods and contain Q-8 as the predominant isoprenoid quinone (Ivanova et al., 2004; Jung et al., 2006). The genus Colwellia was originally proposed by Deming et al. (1988) with the description of two facultatively anaerobic bacteria, Colwellia psychrerythraea and Colwellia hadaliensis. Seven further species have since been added to the genus: Colwellia demingiae, C. hornerae, C. psychrotropica and C. rossensis (Bowman et al., 1998), C. maris (Yumoto et al., 1998), C. piezophila (Nogi et al., 2004) and C. aestuarii (Jung et al., 2006). During a survey of cold-adapted micro-organisms from Arctic sea-ice samples, we isolated a novel psychrotolerant bacterial strain. In this study, we report the isolation and identification of that strain, designated $537^{\mathrm{T}}$. Physiological, biochemical and chemotaxonomic data, together with the results of a phylogenetic analysis based on $16 \mathrm{~S}$ rRNA gene sequences, indicated that the novel isolate represents a novel species of the genus Colwellia.

The GenBank/EMBL/DDBJ accession number for the 16S rRNA gene sequence of strain $537^{\top}$ is DQ007434.

Cellular fatty acid compositions of strain $537^{\top}$ and Colwellia species are presented in a supplementary table available with the online version of this paper.
During the Second Chinese National Arctic Research Expedition cruise of the Chinese ice-breaker M/V Xue Long in August 2003, strain $537^{\mathrm{T}}$ was isolated from sea-ice samples collected from the Canadian Basin $\left(77^{\circ} 30^{\prime} 59^{\prime \prime} \mathrm{N}\right.$ $\left.152^{\circ} 52^{\prime} 04^{\prime \prime} \mathrm{W}\right)$ using a MARK II ice auger. Sea-ice samples were cut carefully into $10-20 \mathrm{~cm}$ sections using a sterile saw and placed in sterile plastic bottles for melting at $4{ }^{\circ} \mathrm{C}$. Strain $537^{\mathrm{T}}$ was obtained using previously described media and methods (Zhang et al., 2006). C. aestuarii DSM $17314^{\mathrm{T}}$ was obtained from the Deutsche Sammlung von Mikroorganismen und Zellkulturen (Braunschweig, Germany). The culture was routinely grown on marine agar 2216 (MA; Difco) or marine broth 2216 (MB; Difco) at $27{ }^{\circ} \mathrm{C}$ and used as a reference strain.

Cell morphology was examined with a Zeiss Axioplan 2 microscope. Colony morphology was observed on MA after incubation at $20{ }^{\circ} \mathrm{C}$ for $24-36 \mathrm{~h}$. The growth temperature was determined with a $\mathrm{TN} 3 \mathrm{~F}$ temperaturegradient incubator (Advantec). The $\mathrm{pH}$ range for growth was determined for the strain in $\mathrm{MB}$ at various $\mathrm{pH}$ values adjusted with $1 \mathrm{M} \mathrm{HCl}$ or $1 \mathrm{M} \mathrm{NaOH}$. General physiological tests were performed using conventional methods (Dong \& Cai, 2001). Acid production from carbohydrates was determined as described by Leifson (1963). Biochemical traits were determined using API kits (API 20E, API 20NE and API ZYM; bioMérieux) according to the manufacturer's instructions, except that the cultures 
were suspended in $3 \%(\mathrm{w} / \mathrm{v}) \mathrm{NaCl}$ solution. Cells of strain $537^{\mathrm{T}}$ were Gram-negative, motile, curved rods. Colonies on MA were white, smooth, circular and convex with entire margins. Strain $537^{\mathrm{T}}$ grew aerobically; growth occurred at $4-26{ }^{\circ} \mathrm{C}$ and the optimal growth temperature was 20 $21{ }^{\circ} \mathrm{C}$. Growth occurred in the presence of $1-6 \%(\mathrm{w} / \mathrm{v})$ $\mathrm{NaCl}$ and no growth occurred in the absence of $\mathrm{NaCl}$.

DNA was extracted and purified as described by Sambrook et al. (1989). The $16 \mathrm{~S}$ rRNA gene was amplified by using a PCR with two universal primers (Zhang et al., 2006). The purified PCR product was ligated to the vector $\mathrm{pMD} 18-\mathrm{T}$ (TaKaRa Bio) and cloned according to the manufacturer's instructions. Sequencing reactions were carried out using the ABI BigDye 3.1 sequencing kit (Applied Biosystems) and an automated DNA sequencer (model ABI3730; Applied Biosystems). The BLAST algorithm was used to search the GenBank and EMBL databases for sequences similar to the almost-complete 16S rRNA gene sequence (1501 bp) obtained for strain $537^{\mathrm{T}}$. A phylogenetic tree was constructed using Kimura two-parameter and pairwisedeletion model analysis implemented in the program MEGA, version 3.0 (Kumar et al., 2004). The resultant tree topology was evaluated by means of a bootstrap analysis based on 1000 replicates. The phylogenetic analysis (Fig. 1) showed that strain $537^{\mathrm{T}}$ grouped with the members of the genus Colwellia, forming a distinct cluster with C. aestuarii DSM $17314^{\mathrm{T}}(97.5 \%)$. The levels of $16 \mathrm{~S}$ rRNA gene sequence similarity between strain $537^{\mathrm{T}}$ and other strains used in the phylogenetic analysis were less than $96 \%$.

Isoprenoid quinones were determined as described previously (Komagata \& Suzuki, 1987), using reversed-phase HPLC. For the analysis of whole-cell fatty acid compositions, strain $537^{\mathrm{T}}$ and C. aestuarii DSM $17314^{\mathrm{T}}$ were grown on MA for 4 days at 20 and $27{ }^{\circ} \mathrm{C}$, respectively. Fatty acid methyl esters were prepared and analysed according to the standard protocol described in the MIDI (Microbial Identification) system (Sasser, 1990). Cells of strain $537^{\mathrm{T}}$ contained Q-8 as the major respiratory quinone. The predominant cellular fatty acids of strain $537^{\mathrm{T}}$ were iso- $\mathrm{C}_{15: 0} \quad 2-\mathrm{OH} \quad$ and/or $\quad \mathrm{C}_{16: 1} \omega 7 c \quad(22.95 \%), \quad \mathrm{C}_{15: 1}$ $(17.64 \%), \mathrm{C}_{17: 1} \omega 8 c(13.74 \%), \mathrm{C}_{16: 0}(7.55 \%)$, iso- $\mathrm{C}_{12: 0}$ $3-\mathrm{OH}(6.45 \%)$ and iso- $\mathrm{C}_{16: 0}(5.69 \%)$; the fatty acid profile resembles those determined for other Colwellia species (Bowman et al., 1998; Nogi et al., 2004; Jung et al., 2006) (see Supplementary Table S1, available in IJSEM Online).

The DNA G $+\mathrm{C}$ content was determined using the thermal denaturation method, with Escherichia coli K-12 as the reference, and DNA-DNA hybridization was performed using the liquid renaturation method (De Ley et al., 1970) as modified by Huß et al. (1983). Both experiments were carried out using a DU800 spectrophotometer (Beckman) with a thermal controller. The DNA G $+\mathrm{C}$ content of strain $537^{\mathrm{T}}$ was $38.9 \mathrm{~mol} \%$ and the DNA-DNA relatedness between strain $537^{\mathrm{T}}$ and C. aestuarii DSM $17314^{\mathrm{T}}$ was $42.5 \%$.

Strain $537^{\mathrm{T}}$ was distinguishable from type strains of Colwellia species by using a combination of physiological and biochemical properties (Table 1). On the basis of these results, strain $537^{\mathrm{T}}$ represents a novel species of the genus Colwellia, for which the name Colwellia polaris sp. nov. is proposed.

\section{Description of Colwellia polaris sp. nov.}

Colwellia polaris (po.la'ris. N.L. fem. adj. polaris polar, referring to the isolation of the type strain from the Arctic Ocean).

Cells are Gram-negative, psychrotolerant, curved rods, 0.6$0.9 \times 0.9-4 \mu \mathrm{m}$. Colonies are non-pigmented, convex, circular and smooth with entire edges. Growth occurs at $4-26{ }^{\circ} \mathrm{C}$ and $\mathrm{pH}$ 5.0-10.0; optimum growth occurs at 20 $21{ }^{\circ} \mathrm{C}$ and approximately $\mathrm{pH}$ 6.0-9.0. Grows aerobically and produces catalase and cytochrome oxidase. Growth occurs in the presence of $1-6 \%(\mathrm{w} / \mathrm{v}) \mathrm{NaCl}$ and no growth occurs in the absence of $\mathrm{NaCl}$. Negative for indole production and in the Voges-Proskauer test. Negative for nitrate reduction and the production of hydrogen sulfide.

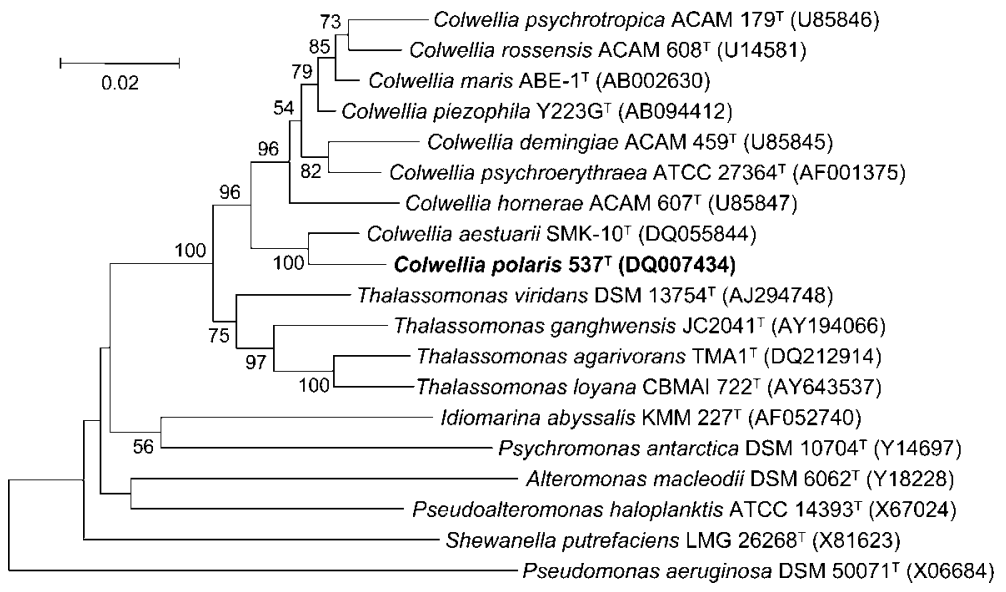

Fig. 1. Neighbour-joining phylogenetic dendrogram, based on 16S rRNA gene sequences, for strain $537^{\top}$ and related species. Bootstrap percentages (based on 1000 resampled datasets) greater than 50\% are shown at branch points. GenBank accession numbers are shown in parentheses. Bar, $2 \%$ sequence divergence. 
Table 1. Phenotypic characteristics that differentiate strain $537^{\top}$ from other Colwellia species

Taxa: 1, strain $537^{\mathrm{T}}$; 2, C. aestuarii (data from Jung et al., 2006); 3, C. psychrerythraea (Deming et al., 1988; Bowman et al., 1998); 4, C. demingiae (Bowman et al., 1998); 5, C. hornerae (Bowman et al., 1998); 6, C. psychrotropica (Bowman et al., 1998); 7, C. rossensis (Bowman et al., 1998); 8, C. maris (Yumoto et al., 1998); 9, C. piezophila (Nogi et al., 2004). +, Positive; -, negative; v (+), variable (type strain positive); NG, no growth on test medium; ND, no data available.

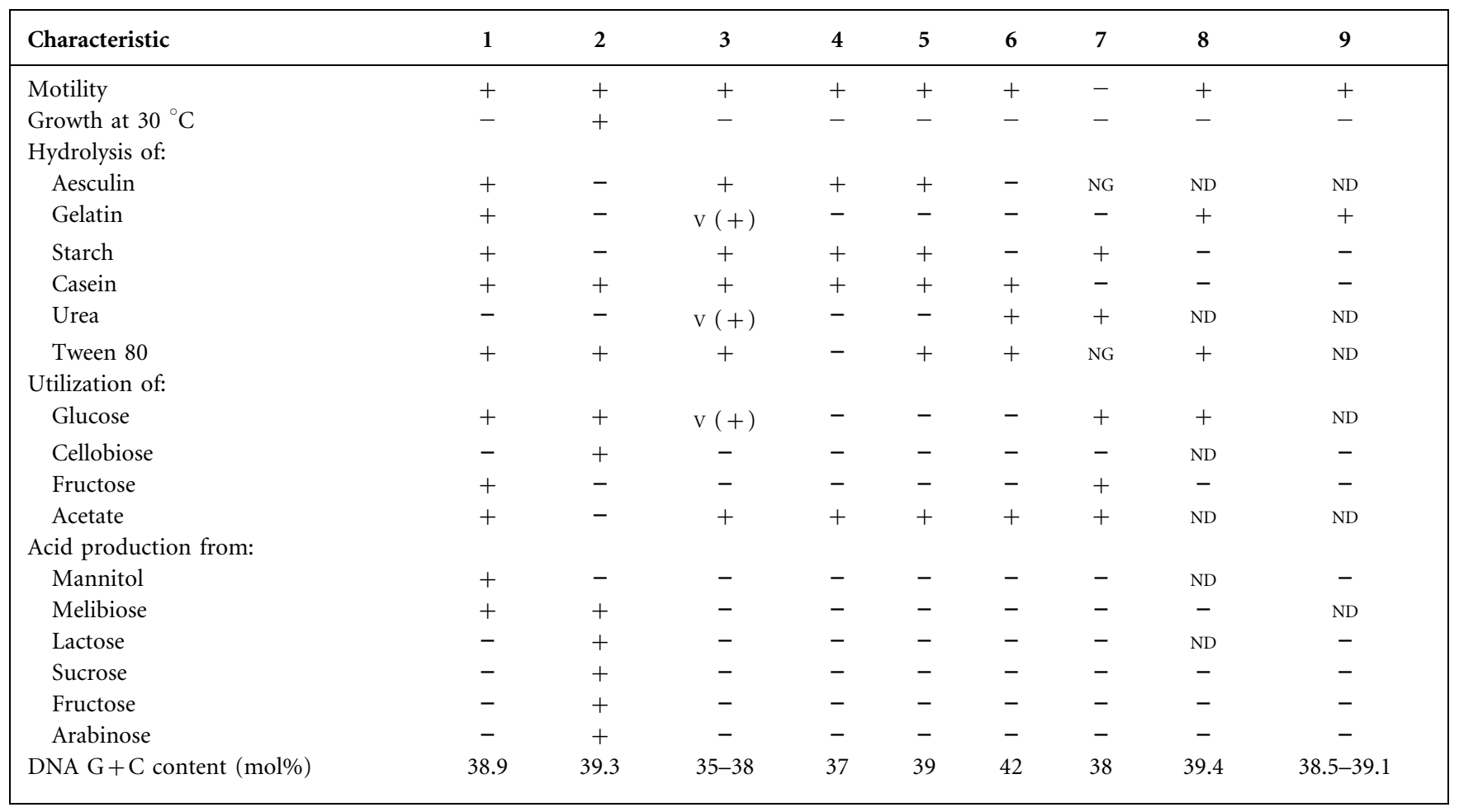

Negative for arginine dihydrolase, lysine decarboxylase, ornithine decarboxylase, citrate utilization, urease, agarase, chitinase, lecithinase, esterase (C4), esterase lipase (C8), lipase (C14), $\alpha$-chymotrypsin, acid phosphatase, trypsin, naphthol-AS-BI-phosphohydrolase, cystine arylamidase, valine arylamidase, $\alpha$-galactosidase, $\beta$-galactosidase, $\beta$-glucuronidase, $\alpha$-glucosidase and $N$-acetyl- $\beta$-glucosaminidase. Positive for gelatinase, caseinase, amylase, alkaline phosphatase and leucine arylamidase. The following substrates are utilized as sole carbon sources: glucose, mannitol, Dmannose, sucrose, D-sorbitol, L-arabinose, maltose, fructose, D-galactose, melibiose, glycerol and pyruvate. The following substrates are not utilized as sole carbon sources: cellobiose, xylose, melezitose, galactitol, erythritol, salicin, lysine, valine, glycine, cysteine, citrate, hippurate, malate, succinate and tartrate. Acid is produced from mannitol, maltose, melibiose, D-galactose and glycerol. The predominant cellular fatty acids are iso- $\mathrm{C}_{15: 0} 2-\mathrm{OH}$ and/or $\mathrm{C}_{16: 1} \omega 7 c$ $(22.95 \%), \mathrm{C}_{15: 1} \quad(17.64 \%), \mathrm{C}_{17: 1} \omega 8 c \quad(13.74 \%), \mathrm{C}_{16: 0}$ $(7.55 \%)$, iso- $\mathrm{C}_{12: 0} 3-\mathrm{OH}(6.45 \%)$ and iso- $\mathrm{C}_{16: 0}(5.69 \%)$. The major respiratory quinone is $\mathrm{Q}-8$. The DNA G+C content of the type strain is $38.9 \mathrm{~mol} \%$.

The type strain, $537^{\mathrm{T}}\left(=\right.$ CGMCC $\left.1.6132^{\mathrm{T}}=\mathrm{JCM} 13952^{\mathrm{T}}\right)$, was isolated from sea ice collected from the Canadian Basin in the Arctic Ocean.

\section{Acknowledgements}

This work was supported by the National Natural Science Foundation of China (grant 30500001) and the National Basic Research Program of China (grant 2004CB719601).

\section{References}

Bowman, J. P., Gosink, J. J., McCammon, S. A., Lewis, T. E., Nichols, D. S., Nichols, P. D., Skerratt, J. H., Staley, J. T. \& McMeekin, T. A. (1998). Colwellia demingiae sp. nov., Colwellia hornerae sp. nov., Colwellia rossensis sp. nov. and Colwellia psychrotropica sp. nov.: psychrophilic Antarctic species with the ability to synthesize

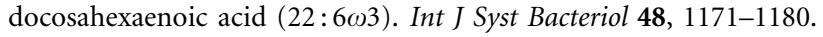

De Ley, J., Cattoir, H. \& Reynaerts, A. (1970). The quantitative measurement of DNA hybridization from renaturation rates. Eur $J$ Biochem 12, 133-142.

Deming, J. W., Somers, L. K., Straube, W. L., Swartz, D. G. \& MacDonell, M. T. (1988). Isolation of an obligately barophilic bacterium and description of a new genus, Colwellia gen. nov. Syst Appl Microbiol 10, 152-160.

Dong, X.-Z. \& Cai, M.-Y. (editors) (2001). Determination of biochemical properties. In Manual for the Systematic Identification of General Bacteria, pp. 370-398. Beijing: Science Press (in Chinese).

Huß, V. A. R., Festl, H. \& Schleifer, K. H. (1983). Studies on the spectrophotometric determination of DNA hybridization from renaturation rates. Syst Appl Microbiol 4, 184-192. 
Ivanova, E. P., Flavier, S. \& Christen, R. (2004). Phylogenetic relationships among marine Alteromonas-like proteobacteria: emended description of the family Alteromonadaceae and proposal of Pseudoalteromonadaceae fam. nov., Colwelliaceae fam. nov., Shewanellaceae fam. nov., Moritellaceae fam. nov., Ferrimonadaceae fam. nov., Idiomarinaceae fam. nov. and Psychromonadaceae fam. nov. Int J Syst Evol Microbiol 54, 1773-1788.

Jung, S.-Y., Oh, T.-K. \& Yoon, J.-H. (2006). Colwellia aestuarii sp. nov., isolated from a tidal flat sediment in Korea. Int J Syst Evol Microbiol 56, 33-37.

Komagata, K. \& Suzuki, K. (1987). Lipid and cell-wall analysis in bacterial systematics. Methods Microbiol 19, 161-207.

Kumar, S., Tamura, K. \& Nei, M. (2004). MEGA3: integrated software for molecular evolutionary genetics analysis and sequence alignment. Brief Bioinform 5, 150-163.

Leifson, E. (1963). Determination of carbohydrate metabolism of marine bacteria. J Bacteriol 85, 1183-1184.
Nogi, Y., Hosoya, S., Kato, C. \& Horikoshi, K. (2004). Colwellia piezophila sp. nov., a novel piezophilic species from deep-sea sediments of the Japan Trench. Int J Syst Evol Microbiol 54, 16271631.

Sambrook, J., Fritsch, E. F. \& Maniatis, T. (1989). Molecular Cloning: a Laboratory Manual, 2nd edn. Cold Spring Harbor, NY: Cold Spring Harbor Laboratory.

Sasser, M. (1990). Identification of bacteria by gas chromatography of cellular fatty acids, MIDI Technical Note 101. Newark, DE: MIDI Inc.

Yumoto, I., Kawasaki, K., Iwata, H., Matsuyama, H. \& Okuyama, H. (1998). Assignment of Vibrio sp. strain ABE-1 to Colwellia maris sp. nov., a new psychrophilic bacterium. Int J Syst Bacteriol 48, 13571362.

Zhang, D.-C., Yu, Y., Chen, B., Wang, H.-X., Liu, H.-C., Dong, X.-Z. \& Zhou, P.-J. (2006). Glaciecola psychrophila sp. nov., a novel psychrophilic bacterium isolated from the Arctic. Int J Syst Evol Microbiol 56, 2867-2869. 